\title{
Extended Stability of Sodium Phosphate Solutions in Polyvinyl Chloride Bags
}

\author{
William Perks, John lazzetta, Pak Cheung Chan, Athina Brouzas, Shirley Law, and Scott E Walker
}

\begin{abstract}
Background: Sodium phosphate injection is used to treat moderate to severe hypophosphatemia. There have been no published reports documenting the physical compatibility or chemical stability of sodium phosphate injection in IV solutions.

Objective: To evaluate the physical compatibility and chemical stability of 30 and $150 \mathrm{mmol} / \mathrm{L}$ solutions of phosphate, prepared from sodium phosphate injection, in 5\% dextrose in water (D5W) and in $0.9 \%$ sodium chloride (normal saline [NS]) and stored in polyvinyl chloride (PVC) bags at $23^{\circ} \mathrm{C}$ or $4^{\circ} \mathrm{C}$ over 63 days.
\end{abstract}

Methods: On study day 0, solutions of phosphate 30 and $150 \mathrm{mmol} / \mathrm{L}$ in D5W or NS were prepared in PVC bags and stored at $4^{\circ} \mathrm{C}$ and $23^{\circ} \mathrm{C}$. On prespecified days during the 63-day study period, the concentrations of sodium and phosphate were determined, and admixture weight was checked to assess moisture loss during storage without a plastic overwrap. Chemical stability was calculated from the intersection of the lower 95\% confidence limit of the degradation rate and the lower limit of acceptability $(90 \%)$ for concentration remaining.

Results: The analytical methods for both sodium and phosphate were found to be precise (coefficient of variation averaging less than $1 \%$ for pre-study validation samples). Both sodium and phosphate retained more than $94 \%$ of the initial concentration over the 63-day study period. With $95 \%$ confidence, the time to achieve $90 \%$ of the initial concentration of both sodium and phosphate approached or exceeded the 63-day study period, regardless of temperature, concentration, or base solution.

Conclusions: Sodium phosphate solutions at a phosphate concentration of 30 or $150 \mathrm{mmol} / \mathrm{L}$ in either NS or D5W retained more than $94 \%$ of the initial concentration of both sodium and phosphate over 63 days when stored at $23^{\circ} \mathrm{C}$ or $4^{\circ} \mathrm{C}$. In compliance with United States Pharmacopeia General Chapter $<797>$ recommendations, a beyond-use date of 14 days (with refrigeration) or $48 \mathrm{~h}$ (room temperature) may be applied. Extending the beyond-use date beyond these limits may be considered, if a validated sterility test is performed.

Keywords: sodium phosphate, drug stability, IV therapy

\section{RÉSUMÉ}

Contexte : Le phosphate de sodium injectable est employé pour traiter l'hypophosphatémie modérée et grave. À ce jour, aucun rapport portant sur la compatibilité physique ou la stabilité chimique du phosphate de sodium injectable contenu dans les solutions intraveineuses n’a été publié.

Objectif : Évaluer la compatibilité physique et la stabilité chimique de solutions de phosphate à des concentrations de 30 et de $150 \mathrm{mmol} / \mathrm{L}$ préparées à partir de phosphate de sodium injectable dilué dans du dextrose à $5 \%$ dans l'eau (D5E) ou du chlorure de sodium à $0,9 \%$ (solution physiologique salée [SP]) puis rangées dans des sacs de polychlorure de vinyle (PVC) à des températures de $4^{\circ} \mathrm{C}$ ou de $23^{\circ} \mathrm{C}$ pendant 63 jours.

Méthodes : Au jour 0 de l'étude, les solutions de phosphate à des concentrations de 30 et de $150 \mathrm{mmol} / \mathrm{L}$ ont été préparées avec du D5E ou de la SP dans des sacs de PVC, puis entreposées à des températures de $4{ }^{\circ} \mathrm{C}$ ou de $23^{\circ} \mathrm{C}$. À des jours donnés pendant la période de 63 jours de l'étude, on a évalué les concentrations de sodium et de phosphate et l'on a pesé les mélanges pour vérifier la perte d'humidité pendant un entreposage n'utilisant pas de suremballage de plastique. La stabilité chimique était calculée au point d'intersection entre la limite inférieure de confiance à $95 \%$ du taux de dégradation et la limite inférieure d'acceptabilité (90\%) de la concentration restante.

Résultats : Les méthodes analytiques employées pour évaluer le sodium et le phosphate se sont révélées précises (coefficient de variation moyen inférieur à $1 \%$ pour les échantillons aux fins de validation avant l'étude). Le sodium et le phosphate conservaient chacun plus de $94 \%$ de leurs concentrations initiales pendant la période d'étude de 63 jours. Avec un niveau de confiance de $95 \%$, le temps nécessaire pour atteindre $90 \%$ de la concentration initiale pour le sodium et pour le phosphate approchait ou dépassait les 63 jours de la période d'étude, peu importe la température, la concentration ou la solution de base.

Conclusions : Les solutions de phosphate de sodium dont la concentration en phosphate est de 30 ou de $150 \mathrm{mmol} / \mathrm{L}$, qu'elles soient à base de $\mathrm{D} 5 \mathrm{E}$ ou de SP, conservaient plus de $94 \%$ des concentrations initiales de sodium et de phosphate pendant 63 jours, qu'elles soient entreposées à des températures de $4{ }^{\circ} \mathrm{C}$ ou de $23^{\circ} \mathrm{C}$. Conformément aux recommandations contenues dans le chapitre $<797>$ de la United States Pharmacopeia, une date limite d'utilisation de 14 jours (sous réfrigération) ou de 48 heures (à température ambiante) peut être utilisée. Allonger la date limite d'utilisation au-delà des bornes fixées par l'organisme américain peut être envisageable si une épreuve validée de stérilité est réalisée.

Mots clés : phosphate de sodium, stabilité des médicaments, traitement par voie intraveineuse 


\section{INTRODUCTION}

Since 2009, Accreditation Canada has required that concen$\checkmark$ trated electrolytes not be stored in client service areas in Canadian hospitals. ${ }^{1}$ This required organizational practice was initially directed at potassium salts, and it was suggested that sodium phosphate be used as an alternative to potassium phosphate to reduce patient risk. ${ }^{2}$ However, the definition of highly concentrated electrolytes has been expanded to include (though is not limited to) sodium phosphate, potassium chloride, potassium phosphate, and sodium chloride at sodium concentrations greater than $0.9 \%{ }^{1}$

Concentrated sodium phosphate injection provides $4 \mathrm{mmol} / \mathrm{mL}$ and $3 \mathrm{mmol} / \mathrm{mL}$ of sodium and phosphate, respectively, ${ }^{3,4}$ At this concentration, the solution must be sufficiently diluted, thoroughly mixed, and infused at an appropriate rate to prevent phlebitis, hypernatremia, hyperphosphatemia, and changes to calcium metabolism. ${ }^{4}$ As a result, many hospital pharmacies have been preparing dilute sodium phosphate solutions, typically in the range of 30 to $150 \mathrm{mmol} / \mathrm{L}$ of phosphate.

There is no indication in the literature that aqueous solutions of sodium or phosphate degrade. However, there is also no published evidence documenting stability to allow the establishment of a beyond-use date (BUD). In assigning a reasonable BUD, which is frequently extended to provide convenience and reduce wastage ${ }^{5-8}$ some additional factors must be considered, including the solubility of sodium phosphate, the storage temperature, the effect of water loss through polyvinyl chloride (PVC) bags, and United States Pharmacopeia (USP) General Chapter <797> recommendations. ${ }^{8}$

The objective of this study was to evaluate the physical compatibility and chemical stability of $30 \mathrm{mmol} / \mathrm{L}$ phosphate and $150 \mathrm{mmol} / \mathrm{L}$ phosphate in $5 \%$ dextrose in water (D5W) or $0.9 \%$ sodium chloride (normal saline [NS]) stored in PVC bags at both room temperature $\left(23^{\circ} \mathrm{C}\right)$ and $4^{\circ} \mathrm{C}$ for 63 days. During the study period, the concentrations of sodium and phosphate were determined on 12 study days, and the solutions were inspected for physical changes (precipitate and colour). In addition, the containers were weighed to detect the extent of water loss by permeation through the PVC containers during storage without an overwrap.

\section{METHODS}

\section{Measurement of Sodium and Phosphate}

Following dilution of sodium phosphate in D5W or NS, the concentration of both sodium and phosphate was determined with the Roche/Hitachi Modular P Chemistry Analyzer (Roche Diagnostics, Laval, Quebec) using methods for clinical investigation approved by Health Canada and the US Food and Drug Administration. Sodium was measured by an indirect ion-selective electrode based on a sodium-selective PVC membrane, and inorganic phosphate was measured on the basis of formation of the ammonium phosphomolybdate complex, $\left(\mathrm{NH}_{4}\right)_{3}\left[\mathrm{PO}_{4}\left(\mathrm{MoO}_{3}\right)_{12}\right]$, with ammonium molybdate in the presence of sulphuric acid. The complex was monitored spectrophotometrically at a wavelength of $340 \mathrm{~nm}$.

The measurement ranges were $10-250 \mathrm{mmol} / \mathrm{L}$ for sodium and 1.6-92 mmol/L for phosphate. Both methods were run daily in the Biochemistry Department of Sunnybrook Health Sciences Centre, where reproducibility is assessed routinely using commercial materials at 2 concentrations, giving long-term imprecision (coefficients of variation [CVs]) of $0.83 \%-1.67 \%$ for sodium and $2.49 \%-3.22 \%$ for phosphate. The accuracy of the methods was ensured through participation in the external quality assurance programs of the Institute for Quality Management in Healthcare (Toronto, Ontario) and the Randox International Quality Assessment Scheme (Crumlin, UK).

\section{Assay Validation}

Prior to the study, the accuracy and reproducibility of measurement of sodium and phosphate were tested by adding sodium phosphate to NS to produce a solution containing $250.15 \mathrm{mmol} / \mathrm{L}$ of sodium and $75 \mathrm{mmol} / \mathrm{L}$ of phosphate. Five samples were tested in duplicate, and the reproducibility of the measured concentrations was calculated on 5 consecutive days. ${ }^{?}$

\section{Stability Study}

On study day 0 , sodium phosphate injection, containing $4 \mathrm{mmol} / \mathrm{mL}$ of sodium and $3 \mathrm{mmol} / \mathrm{mL}$ of phosphate (Sandoz Canada; lot 2106970, expiry July 2015) was diluted in 4 base solutions in PVC containers (Baxter Canada, Mississauga, Ontario): NS in 250-mL bags (lot W4D14C2, expiry July 2015), NS in 100-mL bags (lot W4C25C0, expiry March 2015), D5W in 250-mL bags (lot W4D22C2, expiry July 2015), and D5W in 100-mL bags (lot W4D22C0, expiry April 2015). Eight of each of the following solutions were prepared for analysis: $30 \mathrm{mmol} / \mathrm{L}$ phosphate in $250 \mathrm{~mL} \mathrm{NS}, 30 \mathrm{mmol} / \mathrm{L}$ phosphate in $250 \mathrm{~mL}$ D5W, $150 \mathrm{mmol} / \mathrm{L}$ of phosphate in $100 \mathrm{~mL} \mathrm{NS}$, and $150 \mathrm{mmol} / \mathrm{L}$ phosphate in $100 \mathrm{~mL}$ D5W. Four bags of each of these solutions were stored at room temperature $\left(23^{\circ} \mathrm{C}\right)$, and 4 bags were stored in the refrigerator $\left(4^{\circ} \mathrm{C}\right)$ unprotected from fluorescent room light.

\section{Details of Solution Preparation}

Solutions containing $7.5 \mathrm{mmol}$ phosphate in a total volume of $250 \mathrm{~mL}$ ( $30 \mathrm{mmol} / \mathrm{L}$ ) were prepared by removing the entire volume (including overfill) from 250-mL PVC bags of NS and D5W. Using a calibrated Baxa Repeater pump (Baxter Canada), $247.5 \mathrm{~mL}$ of solution was added to each empty bag. Using a 3 -mL syringe, $2.5 \mathrm{~mL}$ ( $7.5 \mathrm{mmol} / \mathrm{L}$ of phosphate) of sodium phosphate injection was added, resulting in a total volume of $250 \mathrm{~mL}$. Each bag was thoroughly mixed and labelled, and overwrap was not reapplied to any bag. 
Solutions containing $15 \mathrm{mmol}$ phosphate in a total volume of $100 \mathrm{~mL}(150 \mathrm{mmol} / \mathrm{L})$ were prepared by removing the entire volume (including overfill) from 100-mL PVC bags of NS and D5W. Using the same calibrated Baxa Repeater pump, $95 \mathrm{~mL}$ of solution was added to each empty bag. Using a 5-mL syringe, $5 \mathrm{~mL}$ (15 mmol of phosphate) of sodium phosphate injection was added, resulting in a total volume of $100 \mathrm{~mL}$. Each bag was thoroughly mixed and labelled, and overwrap was not reapplied to any bag.

\section{Physical Compatibility}

On study days $0,2,7,9,16,21,23,28,30,35,50$, and 63, samples were drawn from 3 bags of each concentrationtemperature-solution combination for analysis, and were inspected visually for changes in colour, particulate matter, precipitate, and crystals against a white and a black background. The fourth bag of each concentration was weighed every study day on a Mettler AC 100 analytical balance (Mettler-Toledo International Inc, Mississauga, Ontario) to assess volume loss resulting from permeation and evaporation of fluid possibly affecting the concentration of sodium and phosphate.

\section{Sodium and Phosphate Analysis}

On each study day $(0,2,7,9,16,21,23,28,30,35,50$, and 63), the concentrations of sodium and phosphate were determined by the methods described above. The solutions with concentrations of $150 \mathrm{mmol} / \mathrm{L}$ in NS and D5W required 1:1 dilution with distilled water to achieve a concentration within the operating range of the method. After thorough mixing, each sample was analyzed in duplicate to ensure the ability to distinguish concentrations in each concentration-temperaturesolution combination that might differ by $10 \% .^{10,11}$

\section{Data Reduction and Statistical Analysis}

Intraday and interday errors were assessed by the CVs of the sample concentrations determined on each day. After determination of the CV of the assay, a power calculation showed that duplicate analysis had the ability to distinguish between concentrations that differed by at least $10 \%$ within each individual container. ${ }^{10,11}$ Means were calculated for replicate analyses. Mean results from different days for each analysis were compared statistically to determine whether an association existed between the observed result and time. Linear regression and multiple linear regression were used to determine whether there was an association between the observed concentration and study day, solution, or temperature. The $95 \%$ confidence interval (CI) of the percentage remaining on the last study day was calculated for bags stored at $4^{\circ} \mathrm{C}$ and $23^{\circ} \mathrm{C}$. Analysis of variance was used to test differences in concentration on different study days, due to time, temperature, base solution, and phosphate concentration. The 5\% level was used as the a priori cutoff for significance. Sodium and phosphate concentrations were considered "acceptable" or "within acceptable limits" if the lower limit of the $95 \%$ CI of concentration remaining was greater than $90 \%$ of the initial (day 0) concentration.

\section{RESULTS}

Analysis of accuracy and reproducibility during the study period indicated that the sodium and phosphate concentrations were measured accurately and reproducibly. The accuracy of phosphate measurement, based on the mean of duplicate determinations during the validation period, showed an average deviation of $-1.17 \%$ (range $-6.12 \%$ to $3.15 \%$ ) from the expected concentration. Analytical reproducibility within a day, as measured by $\mathrm{CV}$, averaged $0.86 \%$. The accuracy of sodium measurement, based on the mean of duplicate determinations during the validation period, showed an average deviation of $-1.98 \%$ (range $-5.66 \%$ to $-0.86 \%$ ) from the expected concentration. Analytical reproducibility within a day, as measured by $\mathrm{CV}$, averaged $0.58 \%$. These results indicate that differences of $10 \%$ or more could be confidently detected with acceptable error rates ${ }^{10,11}$ with duplicate analysis.

\section{Physical Compatibility and Bag Weights}

Over the 63-day study period, all solutions remained clear and colourless without visible signs of precipitate, particulate matter, or crystals.

Following removal of the overwrap, the 100-mL bags of NS or D5W, with a surface area of $176 \mathrm{~cm}^{2}$, initially weighed an average of $112.2 \mathrm{~g}$. The $250-\mathrm{mL}$ bags of NS or D5W, with a surface area of $256 \mathrm{~cm}^{2}$, initially weighed an average of $263.5 \mathrm{~g}$. Over the 63-day study period, weight loss was greatest for 250-mL bags stored at room temperature. When corrected for surface area, weight loss was similar for the $100-\mathrm{mL}$ bags and 250 -mL bags, ranging from 0.123 to $0.144 \mathrm{mg} / \mathrm{cm}^{2}$ per day at $4^{\circ} \mathrm{C}$ (average $0.132 \mathrm{mg} / \mathrm{cm}^{2}$ per day) and from 0.288 to $0.311 \mathrm{mg} / \mathrm{cm}^{2}$ per day at $23^{\circ} \mathrm{C}$ (average $0.300 \mathrm{mg} / \mathrm{cm}^{2}$ per day). For $100-\mathrm{mL}$ bags, this represents a weight loss of about $3.5 \mathrm{~g}$ or $3.5 \mathrm{~mL}$ of the $100-\mathrm{mL}$ total volume after storage at room temperature for 63 days and $1.2 \mathrm{~g}$ or $1.2 \mathrm{~mL}$ of the $100-\mathrm{mL}$ total volume after storage at $4^{\circ} \mathrm{C}$. For 250 -mL bags, the weight loss was about $4.7 \mathrm{~g}$ or $4.7 \mathrm{~mL}$ of the $250-\mathrm{mL}$ total volume after storage at room temperature for 63 days and $1.8 \mathrm{~g}$ or $1.8 \mathrm{~mL}$ of the $250-\mathrm{mL}$ total volume after storage at $4^{\circ} \mathrm{C}$. These changes in weight due to the loss of water are sufficient to increase the concentration of sodium and phosphate in the bags by about $0.82 \%$ to $3.45 \%$ over the 63 -day study period. The observed percentage loss per day, determined by linear regression, is shown in Tables 1 and 2. 
This single copy is for your personal, non-commercial use only.

For permission to reprint multiple copies or to order presentation-ready copies for distribution, contact CJHP at cjhpedit@cshp.ca

Table 1. Percent Sodium Remaining (Mean \pm SD)* during Storage

\begin{tabular}{|c|c|c|c|c|c|c|c|c|}
\hline \multirow[b]{3}{*}{ Study Day } & \multicolumn{4}{|c|}{ 100-mL PVC Bags } & \multicolumn{4}{|c|}{ 250-mL PVC Bags } \\
\hline & \multicolumn{2}{|c|}{ Normal Saline } & \multicolumn{2}{|c|}{ D5W } & \multicolumn{2}{|c|}{ Normal Saline } & \multicolumn{2}{|c|}{ D5W } \\
\hline & $4^{\circ} \mathrm{C}$ & $23^{\circ} \mathrm{C}$ & $4^{\circ} \mathrm{C}$ & $23^{\circ} \mathrm{C}$ & $4^{\circ} \mathrm{C}$ & $23^{\circ} \mathrm{C}$ & $4^{\circ} \mathrm{C}$ & $23^{\circ} \mathrm{C}$ \\
\hline \multicolumn{9}{|c|}{ Initial sodium concentration (mmol/L) } \\
\hline Expected & 346.3 & 346.3 & 200.0 & 200.0 & 192.5 & 192.5 & 40.0 & 40.0 \\
\hline Observed & $342.0 \pm 0.4$ & $340.0 \pm 0.7$ & $193.0 \pm 0.6$ & $194.3 \pm 0.4$ & $191.7 \pm 0.3$ & $192.5 \pm 0.4$ & $38.7 \pm 1.3$ & $38.7 \pm 1.3$ \\
\hline 2 & $99.22 \pm 0.48$ & $99.71 \pm 0.61$ & $98.10 \pm 0.43$ & $98.29 \pm 0.54$ & $100.00 \pm 0.00$ & $99.57 \pm 0.61$ & $94.84 \pm 2.40$ & $95.27 \pm 1.08$ \\
\hline 7 & $99.32 \pm 1.14$ & $100.10 \pm 0.69$ & $100.18 \pm 2.89$ & $100.34 \pm 0.53$ & $99.91 \pm 0.39$ & $99.66 \pm 0.42$ & $98.72 \pm 1.42$ & $98.29 \pm 1.35$ \\
\hline 9 & $100.00 \pm 0.37$ & $100.20 \pm 0.80$ & $99.31 \pm 0.54$ & $100.35 \pm 1.06$ & $100.17 \pm 0.27$ & $100.09 \pm 0.39$ & $100.45 \pm 1.95$ & $99.15 \pm 1.34$ \\
\hline 16 & $98.54 \pm 0.62$ & $99.71 \pm 0.61$ & $100.18 \pm 1.02$ & $100.86 \pm 1.00$ & $98.70 \pm 0.29$ & $99.31 \pm 0.43$ & $102.60 \pm 1.62$ & $102.16 \pm 1.04$ \\
\hline 21 & $99.71 \pm 0.96$ & $100.49 \pm 0.58$ & $99.66 \pm 0.85$ & $101.55 \pm 1.54$ & $99.39 \pm 0.39$ & $100.09 \pm 0.61$ & $98.29 \pm 1.35$ & $98.72 \pm 1.42$ \\
\hline 23 & $99.81 \pm 0.71$ & $101.67 \pm 0.86$ & $99.48 \pm 0.57$ & $101.03 \pm 1.12$ & $100.96 \pm 0.21$ & $100.95 \pm 0.60$ & $97.85 \pm 1.08$ & $97.41 \pm 0.04$ \\
\hline 28 & $99.71 \pm 0.49$ & $101.18 \pm 0.64$ & $98.96 \pm 0.01$ & $102.06 \pm 1.11$ & $99.74 \pm 0.29$ & $100.09 \pm 0.51$ & $97.85 \pm 1.08$ & $97.85 \pm 1.08$ \\
\hline 30 & $100.10 \pm 0.44$ & $101.18 \pm 1.27$ & $99.48 \pm 0.57$ & $101.54 \pm 0.85$ & $100.09 \pm 0.21$ & $100.35 \pm 0.42$ & $98.72 \pm 1.42$ & $98.29 \pm 1.35$ \\
\hline 35 & $99.81 \pm 0.30$ & $101.96 \pm 0.30$ & $99.48 \pm 0.57$ & $102.23 \pm 0.41$ & $99.83 \pm 0.27$ & $100.69 \pm 0.63$ & $98.29 \pm 1.35$ & $100.01 \pm 1.64$ \\
\hline 50 & $99.91 \pm 1.13$ & $103.23 \pm 1.38$ & $101.21 \pm 1.19$ & $106.00 \pm 1.41$ & $99.57 \pm 0.21$ & $100.26 \pm 0.54$ & $104.32 \pm 1.30$ & $105.60 \pm 0.97$ \\
\hline 63 & $100.39 \pm 1.87$ & $105.00 \pm 0.90$ & $101.21 \pm 0.42$ & $106.52 \pm 0.51$ & $99.91 \pm 0.21$ & $101.65 \pm 0.51$ & $101.73 \pm 1.32$ & $102.59 \pm 0.03$ \\
\hline Slopet (\% change per day) & 0.013 & 0.079 & 0.028 & 0.118 & 0.002 & 0.025 & 0.064 & 0.090 \\
\hline Intercept & 99.41 & 99.33 & 99.10 & 98.94 & 99.90 & 99.63 & 97.95 & 97.48 \\
\hline Sy.x $\neq$ & 0.44 & 0.53 & 0.72 & 0.76 & 0.55 & 0.45 & 2.32 & 2.24 \\
\hline $\mathrm{Cl}$ for slope & \pm 0.016 & \pm 0.019 & \pm 0.025 & \pm 0.027 & \pm 0.020 & \pm 0.016 & \pm 0.082 & \pm 0.079 \\
\hline $\begin{array}{l}\text { Shortest time to achieve } \\
90 \%(95 \% \text { confidence) } \\
\text { (days)§ }\end{array}$ & 355.7 & 102.4 & 186.1 & 69.2 & 469.0 & 246.0 & 68.7 & 59.2 \\
\hline Weight loss (g/day) & 0.022 & 0.055 & 0.024 & 0.055 & 0.033 & 0.074 & 0.037 & 0.074 \\
\hline $\begin{array}{l}\text { Shortest time to achieve } 90 \% \\
\text { after weight correction } \\
\text { (95\% confidence) (days)§ }\end{array}$ & 403.0 & 233.1 & 330.2 & 111.3 & 185.0 & 154.4 & 92.0 & 105.0 \\
\hline \multicolumn{9}{|c|}{$\begin{array}{l}\mathrm{Cl}=\text { confidence interval, } \mathrm{D} 5 \mathrm{~W}=5 \% \text { dextrose in water, } \mathrm{PVC}=\text { polyvinyl chloride, SD = standard deviation. } \\
\text { * Each value is based on duplicate determinations of } 3 \text { samples. Percent remaining is relative to the amount measured on day } 0 \text { (100\%). } \\
+ \text { The slope represents the change in concentration as determined by linear regression of percent remaining on each study day. } \\
\text { The change in concentration is largely due to water loss. } \\
\neq \text { fy.x is the SD of the regression. This is equivalent to the interday variability (error) of the analytical method, expressed as a percentage. } \\
\text { \$Time to achieve } 90 \% \text { of initial concentration (T-90) is based on the degradation rate and is generally regarded as the beyond-use } \\
\text { date. }\end{array}$} \\
\hline
\end{tabular}

\section{Sodium Phosphate Stability}

The initial concentration of sodium and phosphate and the percentage remaining on each study day during the study period are presented in Tables 1 and 2, respectively. For both sodium and phosphate, the $95 \%$ CI for the degradation rate for both sodium and phosphate encompassed zero (i.e., $0 \% /$ day) for solutions stored at $4^{\circ} \mathrm{C}$. For solutions stored at $23^{\circ} \mathrm{C}$, the apparent degradation rate was positive, and the entire $95 \% \mathrm{CI}$ was also positive, indicating an apparent increase in concentration. When the concentrations of sodium and phosphate were corrected for the observed weight loss, the $95 \% \mathrm{CI}$ for the degradation rate included a rate of $0 \% /$ day for all of the phosphate measurements and half of the sodium measurements.

As a result of the number of sampling days, base solutions, concentrations, and temperatures, analysis of variance was able to detect significant differences in percentage remaining due to temperature $(p<0.001)$, base solution $(p<0.03)$, study days $(p<0.001)$, and concentration $(p<0.001)$ for both sodium and phosphate. In all cases, the difference was $1 \%$ or less for sodium and about $0.8 \%$ or less for phosphate. The most readily apparent differences in concentration were related to temperature and bag volume and can be directly attributed to weight loss resulting in an increase in concentration, rather than to degradation of the sodium or phosphate. When sodium and phosphate concentrations were corrected for water loss, analysis of variance was able to detect significant differences in percentage remaining due to study day $(p<0.002)$ and concentration $(p=0.003$ for phosphate only, not sodium), but not temperature or base solution. The detectable difference in concentration was less than $0.5 \%$.

When a $95 \%$ CI for the degradation rate was determined and then used to calculate the time to achieve $90 \%$ of the initial concentration, for both sodium and phosphate, the time approached or exceeded the 63-day duration of the study, regardless of temperature, concentration, or base solution. When the concentration was corrected for water loss, the shortest time to achieve $90 \%$ of the initial concentration, with $95 \%$ confidence, was generally and always exceeded the duration of the study period (63 days). 
This single copy is for your personal, non-commercial use only.

For permission to reprint multiple copies or to order presentation-ready copies for distribution, contact CJHP at cjhpedit@cshp.ca

Table 2. Percent Phosphate Remaining (Mean \pm SD)* during Storage

\begin{tabular}{|c|c|c|c|c|c|c|c|c|}
\hline \multirow[b]{3}{*}{ Study Day } & \multicolumn{4}{|c|}{ 100-mL PVC Bags } & \multicolumn{4}{|c|}{ 250-mL PVC Bags } \\
\hline & \multicolumn{2}{|c|}{ Normal Saline } & \multicolumn{2}{|c|}{ D5W } & \multicolumn{2}{|c|}{ Normal Saline } & \multicolumn{2}{|c|}{ D5W } \\
\hline & $4^{\circ} \mathrm{C}$ & $23^{\circ} \mathrm{C}$ & $4^{\circ} \mathrm{C}$ & $23^{\circ} \mathrm{C}$ & $4^{\circ} \mathrm{C}$ & $23^{\circ} \mathrm{C}$ & $4^{\circ} \mathrm{C}$ & $23^{\circ} \mathrm{C}$ \\
\hline \multicolumn{9}{|c|}{ Initial phosphate concentration (mmol/L) } \\
\hline Expected & 150.0 & 150.0 & 150.0 & 150.0 & 30.0 & 30.0 & 30.0 & 30.0 \\
\hline Observed & $155.2 \pm 0.6$ & $154.7 \pm 1.8$ & $154.3 \pm 1.2$ & $154.9 \pm 1.5$ & $31.5 \pm 0.3$ & $31.7 \pm 0.3$ & $31.1 \pm 0.3$ & $31.4 \pm 0.3$ \\
\hline 2 & $99.22 \pm 0.43$ & $97.45 \pm 2.08$ & $99.21 \pm 0.90$ & $99.42 \pm 1.59$ & $99.44 \pm 0.65$ & $98.68 \pm 0.80$ & $99.30 \pm 1.45$ & $98.76 \pm 0.66$ \\
\hline 7 & $99.44 \pm 1.27$ & $99.23 \pm 0.87$ & $98.64 \pm 3.13$ & $99.31 \pm 1.21$ & $97.89 \pm 0.90$ & $98.42 \pm 1.07$ & $98.80 \pm 1.06$ & $98.92 \pm 0.48$ \\
\hline 9 & $98.87 \pm 0.48$ & $99.33 \pm 0.55$ & $99.23 \pm 0.81$ & $100.23 \pm 1.35$ & $98.76 \pm 0.83$ & $99.10 \pm 0.79$ & $99.45 \pm 0.86$ & $98.87 \pm 0.77$ \\
\hline 16 & $101.44 \pm 1.08$ & $100.76 \pm 1.87$ & $100.02 \pm 2.01$ & $101.77 \pm 1.50$ & $100.45 \pm 0.63$ & $100.46 \pm 0.86$ & $101.11 \pm 0.241$ & $100.41 \pm 1.15$ \\
\hline 21 & $100.24 \pm 1.75$ & $101.49 \pm 1.59$ & $100.22 \pm 1.07$ & $102.64 \pm 1.33$ & $100.57 \pm 0.60$ & $101.23 \pm 0.89$ & $100.09 \pm 3.991$ & $101.07 \pm 1.15$ \\
\hline 23 & $100.36 \pm 2.41$ & $101.71 \pm 0.56$ & $101.14 \pm 0.52$ & $102.89 \pm 0.96$ & $100.05 \pm 0.67$ & $100.26 \pm 1.32$ & $101.10 \pm 0.911$ & $100.88 \pm 0.70$ \\
\hline 28 & $100.58 \pm 1.61$ & $102.56 \pm 1.55$ & $101.14 \pm 0.95$ & $103.16 \pm 0.88$ & $99.47 \pm 1.17$ & $99.47 \pm 0.88$ & $100.39 \pm 0.601$ & $100.09 \pm 0.76$ \\
\hline 30 & $98.28 \pm 0.97$ & $98.82 \pm 1.44$ & $98.10 \pm 0.50$ & $100.04 \pm 1$ & $98.08 \pm 0.51$ & $97.92 \pm 0.86$ & $98.54 \pm 1.70$ & $99.02 \pm 0.73$ \\
\hline 35 & $98.22 \pm 1.46$ & $100.50 \pm 1.06$ & $98.28 \pm 1.06$ & $100.96 \pm 0$ & $98.29 \pm 1.24$ & $99.40 \pm 0.61$ & $99.28 \pm 1.20$ & $99.09 \pm 0.81$ \\
\hline 50 & $99.60 \pm 1.30$ & $101.96 \pm 0.74$ & $99.01 \pm 0.68$ & $102.84 \pm 1.76$ & $98.16 \pm 1.39$ & $98.87 \pm 1.46$ & $99.19 \pm 0.80$ & $99.69 \pm 0.33$ \\
\hline 63 & $100.97 \pm 2.42$ & $105.34 \pm 1.31$ & $100.88 \pm 0.24$ & $104.92 \pm 1.78$ & $100.25 \pm 0.62$ & $101.46 \pm 0.80$ & $100.45 \pm 1.161$ & $101.53 \pm 0.75$ \\
\hline Slopet (\% change per day) & 0.008 & 0.084 & 0.008 & 0.073 & -0.003 & 0.017 & 0.004 & 0.023 \\
\hline & 9.59 & 98.77 & 99.47 & 99 & 99.35 & 99.21 & 99.72 & 99 \\
\hline Sy.x‡ & .06 & 1.36 & 1.11 & & 1.05 & 1.11 & 0.89 & 0 \\
\hline $\mathrm{Cl}$ for slope & \pm 0.037 & \pm 0.048 & \pm 0.039 & \pm 0.041 & \pm 0.037 & \pm 0.039 & \pm 0.031 & \pm 0 \\
\hline $\begin{array}{l}\text { Shortest time to achieve } 90 \% \\
(95 \% \text { confidence) (days)§ }\end{array}$ & 224.0 & 75.8 & 213.2 & 87.9 & 251.2 & 180.1 & 287.3 & 185.1 \\
\hline Weight loss (g/day) & 22 & 0.055 & 0.024 & & 0.033 & 0.074 & 0.037 & 0.074 \\
\hline $\begin{array}{l}\text { Shortest time to achieve } 90 \% \\
\text { after weight correction } \\
\text { (95\% confidence) days§ }\end{array}$ & 194.7 & 129.7 & 182.7 & 168.9 & 137.9 & 103.8 & 154.9 & 121.1 \\
\hline \multicolumn{9}{|c|}{$\begin{array}{l}\mathrm{Cl}=\text { confidence interval, D5W = 5\% dextrose in water, PVC = polyvinyl chloride, SD = standard deviation. } \\
\text { * Each value is based on duplicate determinations of } 3 \text { samples. Percent remaining is relative to the amount measured on day } 0 \text { (100\%). } \\
+ \text { †The slope represents the change in concentration as determined by linear regression of the percent remaining on each study day. } \\
\text { The change in concentration is largely due to water loss. } \\
\neq \text { fSy.x is the SD of the regression. This is equivalent to the interday variability (error) of the analytical method, expressed as a } \\
\text { percentage. } \\
\S \text { STime to achieve } 90 \% \text { of initial concentration (T-90) is based on the degradation rate and is generally regarded as the beyond-use date. }\end{array}$} \\
\hline
\end{tabular}

\section{DISCUSSION}

The $95 \%$ CI for the degradation rate for both sodium and phosphate included a rate of $0 \% /$ day for solutions stored at $4^{\circ} \mathrm{C}$. With storage at $23^{\circ} \mathrm{C}$, the apparent degradation rate (change in concentration) was positive, and the entire $95 \%$ CI was also positive, indicating an apparent increase in concentration. When the concentrations of sodium and phosphate were corrected for the observed weight loss, the $95 \% \mathrm{CI}$ for the degradation rate included a rate of $0 \% /$ day for all of the phosphate measurements and half of the sodium measurements. These results indicate that the most important variable affecting the concentration of sodium or phosphate in PVC bags in this study was related to water loss. Water loss increased with both temperature and the surface area of the PVC bag.

After correction of the sodium and phosphate concentrations for the loss of weight attributed to permeation of water through the PVC container and subsequent evaporation, the time to achieve $90 \%$ of the initial concentration exceeded the study period of 63 days, averaging more than 200 days for sodium and 149 days for phosphate. These results demonstrate the relative stability, or lack of degradation, of both components. Nevertheless, we are unaware of any published studies documenting the chemical stability of sodium phosphate injection following dilution in IV solutions.

When considering the stability of sodium phosphate, it should be recognized that although the element sodium has 20 known isotopes, effectively 100\% of the sodium on Earth exists as the stable, nonradioactive form, ${ }^{23} \mathrm{Na}$. Therefore, sodium is generally regarded as a stable element that does not degrade. In contrast, elemental phosphorus is not found as a free element on Earth. It has a single naturally occurring isotope, but in biological systems, phosphorus is found as a free phosphate ion in solution. In dilute aqueous solutions, free phosphate ion exists in 4 forms. In strongly acidic conditions, aqueous phosphoric acid $\left(\mathrm{H}_{3} \mathrm{PO}_{4}\right)$ is the primary form, although some amount of each of the other 3 forms will be present and in equilibrium with all other forms. A shift from one form to another does not indicate instability. In fact, there is no evidence in the literature that phosphate degrades. 


\section{CONCLUSION}

In this study, sodium and phosphate concentrations in IV admixtures prepared and stored in PVC containers increased over the 63-day study period as a result of water loss from the PVC bags. When measurements were corrected for water loss, the concentrations of both sodium and phosphate remained unchanged, and the $95 \% \mathrm{CI}$ of the degradation rate encompassed a loss rate of $0 \% /$ day. The chemical stability of sodium phosphate IV admixtures, calculated from the intersection of the lower $95 \%$ confidence limit of the degradation rate and the limit of acceptability (90\%), approached or exceeded the study duration for both components at both $4^{\circ} \mathrm{C}$ and $23^{\circ} \mathrm{C}$.

In compliance with United States Pharmacopeia General Chapter $<797>$ recommendations, a BUD of 14 days (with refrigeration) or $48 \mathrm{~h}$ (room temperature) may be applied. Although the results of this study show extended chemical stability of sodium phosphate admixtures that exceeds USP General Chapter <797> BUD limits, the BUD can be extended only if a validated sterility test is performed on each batch prepared.

\section{References}

1. Concentrated electrolytes. In: Required Organizational Practices handbook 2017. Ottawa (ON): Accreditation Canada; 2016 [cited 2016 Jun 14]. pp. 42-3. Available from: https://accreditation.ca/sites/default/files/rophandbook-2017.pdf

2. Safety strategies for potassium phosphates injection. ISMP Can Saf Bull. 2006;6(2):1-2.

3. Sodium phosphates injection, P3 $\mathrm{mmol} / \mathrm{mL}$ [product monograph]. Boucherville (QC): Sandoz Canada, Inc; 2011.

4. Newton DW, Driscoll DF. Chemistry and safety of phosphates injections. Am J Health Syst Pharm. 2008;65(18):1761-6.

5. Walker SE, Hanabusa Y, Dranitsaris G, Bartle WR, Iazzetta J. Cost effective evaluation of a stability study. Can J Hosp Pharm. 1987;40(4):1138.

6. Walker SE, DeAngelis C, Iazzetta J, Gafni A. Chemotherapy waste reduction through shelf-life extension. Can J Hosp Pharm. 1994;47(1):15-23.

7. Kastango ES, Bradshaw BD. USP chapter 797: establishing a practice standard for compounding sterile preparations in pharmacy. Am J Health Syst Pharm. 2004;61(18):1928-38.

8. USP General Chapter <797> pharmaceutical compounding-sterile preparations. In: USP compounding compendium. Rockville (MD): US Pharmacopeial Convention, Inc; 2016. p. 39-84.
9. Shah VP, Midha KK, Dighe S, McGilveray IJ, Skelly JP, Yacobi A, et al. Analytical methods validation: bioavailability, bioequivalence, and pharmacokinetic studies. J Pharm Sci. 1992;81(3):309-12.

10. Freiman JA, Chalmers TC, Smith H Jr, Kuebler RR. The importance of beta, the type II error and sample size in the design and interpretation of the randomized control trial. Survey of 71 "negative" trials. $N$ Engl J Med. 1978;299(13):690-4.

11. Stolley PD, Strom BL. Sample size calculations for clinical pharmacology studies. Clin Pharmacol Ther. 1986;39(5):489-90.

William Perks, BScPhm, is Manager of Pharmacy Manufacturing, Sunnybrook Health Sciences Centre, Toronto, Ontario.

John lazzetta, PharmD, is Coordinator of Drug Information, Sunnybrook Health Sciences Centre, and Assistant Professor, Leslie Dan Faculty of Pharmacy, University of Toronto, Toronto, Ontario.

Pak Cheung Chan, PhD, DABCC, FCACB, is a Clinical Biochemist in the Department of Clinical Pathology, Sunnybrook Health Sciences Centre, and Assistant Professor, Faculty of Medicine, University of Toronto, Toronto, Ontario.

Athina Brouzas, BSc, is a Senior Medical Laboratory Technologist in the Department of Clinical Pathology, Sunnybrook Health Sciences Centre, Toronto, Ontario.

Shirley Law, DipPharmTech, is a Research Assistant in Quality Control, Department of Pharmacy, Sunnybrook Health Sciences Centre, Toronto, Ontario

Scott E Walker, MScPhm, is Director of Pharmacy, Sunnybrook Health Sciences Centre, and Associate Professor, Leslie Dan Faculty of Pharmacy, University of Toronto, Toronto, Ontario.

Competing interests: None declared.

Address correspondence to:

Scott E Walker

Pharmacy

Sunnybrook Health Sciences Centre

2075 Bayview Avenue

North York ON M4N 3M5

e-mail: scott.walker@sunnybrook.ca

Funding: This study was funded by the Department of Pharmacy, Sunnybrook Health Sciences Centre. All drugs and supplies were purchased by the department, and all testing was completed at Sunnybrook. 